\title{
Maori media production, civic journalism and the foreshore and seabed controversy in Aotearoa
}

\begin{abstract}
This article explores the social significance of increased media production by Maori in Aotearoa/New Zealand as an opportunity for challenging a tendency in mainstream journalism to promote Pakeha perspectives. The analysis focuses on the recent documentary Hikoi, which was initiated by two young Maori women as a challenge to media framing of Maori protests as 'unjustified' and 'disruptive' acts. We argue that this documentary illustrates the potential for civic journalists to broaden public deliberations regarding political issues such as the foreshore and seabed controversy.
\end{abstract}

DARRIN HODGETTS, ALISON BARNETT, ANDREW DUIRS, JOLENE HENRY and ANNI SCHWANEN

University of Waikato

ITIZENS often learn about what is happening in different communi ties, what issues are important, and how these issues should be re solved via news reports. Media have become central to intergroup relations and can extend awareness and dialogue between groups (Hodgetts, Masters \& Robertson, 2004). However, not all communities are represented equally or have the opportunity to represent themselves on their own terms. Media portrayals of minority groups often maintain distinctions between 'us' the majority audience addressed by reports and 'them' the minority audience portrayed by these same reports (Adebanwi, 2004; Hall, 1997). Indigenous voices, including those of Maori in Aotearoa/New Zealand, can be disadvantaged by news coverage, which often functions to silence Maori, while rely- 
ing on non-Maori voices to frame issues concerning Maori (Barclay \& Lui, 2003; Rankin \& McCreanor, 2004). More pointedly, mainstream news media have played a central role in processes of colonisation; being used as a tool for convincing colonising and colonised groups that what was occurring was in the interests of 'everyone' (Adebanwi, 2004; Spoonley \& Hirsh, 1990).

Research has documented how throughout New Zealand history when Maori have asserted rights to land and autonomy from Pakeha regulation, news coverage has been partial, providing little background to grievances and dismissing Maori concerns as unreasonable and unnecessarily hostile (Curnow, Hopa \& McRae, 2002; Barclay \& Lui, 2003). Today, even when contributing to media discussions of health and social concerns faced by their own communities, Maori commentators are forced to continuously defend any references to structural inequalities or colonisation ${ }^{1}$ (Hodgetts, Masters \& Robertson, 2004). Recent coverage of the Foreshore and Seabed controversy exemplifies the framing of Maori claims to guardianship as unreasonable and disruptive threats to Pakeha control and the national interest. Typical examples include 'Cullen talks tough on Maori protest' (The Press, 10 December 2003, p. 6) and 'Tempers flare as hikoi [protest] marches in' (Waikato Times, 30 April 2004, p. 2). Such items have contributed to a climate of misunderstanding between Maori and settler communities and the hasty development of new legislation that once again displaces Maori indigenous rights (cf., Maihi, 2003; Walker, 2002).

By way of background, the contemporary controversy surrounding the foreshore and seabed began with a court case over land ownership in the Marlborough Sounds and associated rights to commercial aquaculture ventures. In 1997 local Maori lodged a case with the Maori Land Court to assert their rights to the foreshore and seabed. After years of legal battles the claim reached the Court of Appeal who in June 2003 found that the Maori Land Court had the jurisdiction to determine whether or not the foreshore and seabed of the Marlborough Sounds was Maori Land. This resulted in considerable controversy in the New Zealand media over the implications of Maori ownership for general public access to the beaches and waterways (Maihi, 2003). The current Foreshore and Seabed legislation was developed by the Labour government to remove the legal right of Maori to take a case to the Maori Land court and to thus appease the anxieties of the Pakeha majority.

The ability to dismiss or regulate 'away' Maori grievances is linked to the settler society's control over governmental and media institutions (Curnow, 192 PACIFIC JOURNALISM REVIEW 11 (2) 2005 
Hopa \& McRae, 2002). Such symbolic power involves the ability of groups to intervene in unfolding events, and to influence the framing of issues (Peitikaninen, 2003). This power to name and define issues is linked to economic and social privilege. That is, economically and socially advantaged groups monopolise deliberations regarding issues affecting other peoples' lives and consequently reproduce and maintain their own economic and symbolic privilege (Couldry \& Curran, 2002). The resulting news coverage does more than transmit information about events. Such coverage actively shapes events in a way that limits the scope for public deliberation regarding indigenous rights. As Pietikaninen (2003) writes:

For any group, let alone a minority, news coverage is a means of gaining wider attention for their agenda, of making their voices heard, and of possibly making a difference on issues important to them. News is also a highly controlled forum of ideas and voices. It not only gives room for the flow of ideas and information, but it may also inhibit this flow. (p. 583)

Journalistic processes involving the naming of issues and silencing of voices have very real implications for the position of indigenous people in society and their rights and life chances (Hall, 1997). This is overtly evident when protest actions are repeatedly taken out of context and presented as pointless disruptive acts (Barclay \& Lui, 2003; Rankin \& McCreanor, 2004).

To this point we have considered the function of mainstream media in shaping race relations and the dismissal of Maori concerns in Aotearoa. Let us now consider the significance of Maori media as an alternative site for dialogue and representation. From print and radio to television and the internet, Maori have a history of using media to preserve cultural practices and to organise resistance to colonisation (Fox, 1990; Stuart, 2003; Walker, 1990). In fact, Maori quickly realised the need for media production, developing the first Maori language newspaper in 1842 and producing radio broadcasts from 1942. These developments enabled Maori to engage in deliberations regarding indigenous rights and represent a community-based tradition of media production that has continued intermittently through to the present day (Curnow, Hopa \& McRae, 2002; Whaanga, 1990; Fox, 1992). Recent increases in Maori media production have proved crucial for providing direct links within Maori communities, for nurturing a sense of community, for edu- 
cation, and for fostering a shared agenda necessary for continued advocacy for social justice (Stuart, 2003). As a site for social intervention, Maori media have also provided a training ground for Maori media professionals, and a wider understanding of news media processes among Maori. Such understandings are crucial for civic participation (Couldry \& Curran, 2002; Walker, 2002).

Despite exemplifying such positive features, Maori media have often been marginalised and under resourced, and have not displaced the regulatory power of Pakeha institutions (Fox, 1992). The existence of Maori media may contribute to mainstream media sidestepping their obligations to represent indigenous concerns in an equitable manner (Whaanga, 1990). Challenging the symbolic power held by the settler society and ensuring Maori participation in public decision-making processes necessitates Maori gaining a legitimate voice within mainstream media (Barclay \& Liu, 2003). Walker proposes that Maori struggles against historic injustices involve liberating both themselves and Pakeha. 'The aim is to get those entrusted with power over the lives of Maori to act justly as promised under the Treaty of Waitangi' (2002, p. 225). This necessitates balance in coverage of collective action and expressions of agency among Maori, as well as attempts to educate the general public about the origins of such events (cf., Spoonley \& Hirsh, 1990). Maori participation in mainstream media coverage is necessary because the resources communities have to respond to colonisation are determined by policy processes often occurring through the media beyond the borders of our communities (Hodgetts, Masters \& Robertson, 2004).

Consideration of issues surrounding media power and social participation take us into the realm of civic or public journalism, and recent attempts by media professionals to promote marginalised voices in public deliberations regarding issues affecting local communities. Civic journalists propose that the purpose of news is to improve situations, rather than merely report on problems. This approach responds to growing frustration among many groups who feel their voices have not been heard and their issues have not been presented fairly within news coverage (Wallack, Woodruff, Dorfman \& Diaz, 1999). Civic journalists aim to invigorate the public sphere and increase democratic participation by promoting the production of self-representations among marginalised groups. This involves a shift from a 'journalism of information' to a 'journalism of conversation' and the abandonment of traditional notions of the 'detached observer' who reports on the issues in favour of the journal-

194 PACIFIC JOURNALISM REVIEW 11 (2) 2005 
ist as collaborator who works with groups to make the news (Lambeth, Meyer $\&$ Thorson, 1998). In terms of race relations, journalists facilitate the participation of minority communities in the identification and framing of local issues and wider decision-making processes (Hippocrates, 1998). A broader goal of such projects is to foster a politically literate public whose deliberations are informed by more than the common sense views of a dominant group ${ }^{2}$.

The recent documentary Hikoi-Inside Out (TV1, 21 July 2004) provides an example of Maori self-representation through mainstream media. This documentary has its origins in the longstanding traditions of Maori media production. What makes the Hikoi documentary unique is that it was constructed from the perspective of two young Maori women involved in organizsing the Hikoi, and constitutes an attempt by Maori to inform the wider public about the catalysts for and rationale behind this recent protest action. We explore how this documentary's portrayal of a foreshore and seabed protest as a positive action departs from the tendency in mainstream media to frame 'Maori news as bad news' (Rankine \& McCreanor, 2004; Walker, 2002).

\section{Methodology}

Questions concerning the role of television in challenging or supporting established power relations have shaped media research (Couldry \& Curran, 2002). Researchers presenting somewhat pessimistic perspectives have proposed that television functions on behalf of powerful social groups. Conversely, those presenting more optimistic perspectives have proposed that television functions on behalf of the public, holding politicians and members of powerful social groups accountable for their actions. Neither perspective has proven adequate in fully capturing the complex and varied functions of television. Consequently, we explore television as a force for both social domination and change, as both reflecting and restricting the interests of Maori. The idea that television provides an institutionally mediated cultural forum centralises the notion that coverage reflects, refracts, circulates, and helps create public images of intergroup relations in society. It highlights the socially progressive possibilities of coverage while also acknowledging the restrictions often imposed through the concentration of symbolic power within institutions controlled by the settler society.

Documentary provides an appropriate media form for investigating these processes because it has a long history of use among political movements for foregrounding grievances and promoting social change through the projec- 
tion of suppressed perspectives into public dialogue (Abrash \& Whiteman, 1999). In addition to providing a resource for reinvigorating solidarity and binding a social movement to a shared agenda, documentary is important because it becomes part of 'the public record' as a document that 'reflects' past events and intergroup relationships (Gaines \& Renov, 1999). The extended nature and calm expositional style of documentary also provides a level of credibility regarding the newsworthiness of portrayed events that is not as pronounced for other media forms.

A text and context narrative approach was used to focus the analysis beyond the description of this specific documentary in order to make broader observations about how social and cultural relationships were being storied (Hodgetts, Masters \& Robertson, 2004). Generally, the analysis involved moving from repeated interactions with the documentary, to the initial coding of core story elements and the development of an interpretation that represents the overall narrative being promoted by the programme. Each author watched the entire documentary several times and took notes containing issues of interest. We then met to discuss emerging issues and recontextualise core themes in relation to the overall plot of the documentary. A plot synopsis for the story was then constructed to capture the function of various narrative elements and characters in the story's progression. Throughout, our interactions with the documentary were top down, in the sense of being informed by the existing literature on documentary form, symbolic power and media representations of indigenous peoples. The process was also bottom up, in the sense of generating ideas from the documentary and seeking literature to inform an overall interpretation. This communal process also enabled our group of Maori and Pakeha scholars to engage in frank conversations about the events and issues depicted.

\section{Documentary as site for interracial dialogue}

Our analysis focuses on the social relevance of this programme's framing of Maori protest action and what this reveals about the potential to challenge historical trends in the domination of a Pakeha perspective on race relations in Aotearoa. Specifically, we examine the significance of this documentary in establishing an historical context for the Hikoi, reframing relationships between Maori and the Crown, and promoting the legitimacy of Maori grievances through positive portrayals of protesters. What follows is a brief syn- 
opsis of the documentary that will orientate readers to the overall framing of the foreshore and seabed issue.

Simon Dallow introduces the programme by addressing the viewing public: '...many of $u s$ are still confused by the legal complexities of the foreshore and seabed debate, but what is clear is that it prompted united action by Maori on a scale never seen before'. Such direct appeals to the wider public maintain a mode of address through which a Maori perspective is communicated primarily to a Pakeha audience in an effort to educate and inform them regarding catalysts for and the nature of this protest. The documentary then follows the announcement of the Hikoi to protest the government's proposed foreshore and seabed legislation. The audience is told that they will follow two young women (Te Whenua Harawira and Tere Harrison) with the Hikoi from 'the far north to Parliament' and explore the reasons for this protest action. The camera then transports the audience from the far north, down Ninety Mile Beach, to the north shore of Auckland, through south Auckland and the Waikato, to Taupo and the Hawkes Bay, and subsequently Wanganui, Martinborough and Wellington. The journey is punctuated with inserts from experts, including Iwi (tribal) representatives, lawyers and Crown representatives. These inserts are used to establish and reinforce the legitimacy of Maori concerns as a response to a history of land confiscations by the Crown. The documentary builds momentum through sequences focusing on the experiences of Hikoi participants. Increasingly important are assertions of identity and shared purpose across Iwi, and the need to educate Pakeha and cultivate their understanding of Maori activism. The documentary concludes by illustrating the growing political mobilisation of Maori from a few hundred people who started the journey in the far north to between 20,000 to 30,000 people protesting outside the steps of Parliament.

\section{Establishing an historical context for the Hikoi}

In the past, rather than being depicted as positive, unifying and empowering acts, Maori protests have been portrayed by mainstream media as rebellious disruptions to presumed social harmony (Walker, 2002). For example, although raising awareness about the existence of grievances and leading to the establishment of bodies such as the Waitangi Tribunal, many of the noisy but peaceful mobilisations of the last three decades have been depicted in the media as 'full-scale riots' and as bad news for the Pakeha majority. The Hikoi 
documentary makes reference to such historical protest movements, in order to present a different interpretation of such protests as reasoned responses to ongoing injustices that express Maori identity and unity. The need to consciously reframe such protests in this way testifies to the taken for granted status of Pakeha perspectives, and Maori understandings of the importance of promoting alternative representations.

An effective strategy for resisting the dismissal of the Hikoi is to position it as part of a larger pattern of resistance to colonisation and associated injustices. Perhaps the most overt reference to past protests is the use of file footage of the 1975 land march; the steps of which the Hikoi is tracing. The use of such file footage and protest songs establishes a context for the present protest action based on similarities between the past and the present. The sequence begins with sunrise over the coastline and a graphic insert stating '22nd April 2004-Cape Reinga'. Te Whenua then introduces herself as the audience's guide and explains a scene at a car park where protesters are gathering for a karakia to begin the march. The beginning of the journey is signalled by the lyrics 'there is a movement, movement on your feet, shuffle to the beat... maranga ake ai'. Such background music played an integral part in the documentary by underlying the aims of the Hikoi. Waiata (songs) were repeatedly used to suggest positive aspects of being Maori and the need for uniting and to advocate for collective rights and the retention of Taonga [treasures], including the foreshore and seabed.

The camera then shifts to the beginning of the march and captures images of protesters, both young and old, beginning the journey to Wellington. Walking beside Te Whenua is a man holding a Taonga in the form of a large carved pole with a flag on it. The camera then cuts back to footage of the 1975 Land march depicting another young man carrying the same Taonga. The interweaving of images depicting the use of this same Taonga today with images of Dame Whina Cooper walking to Wellington in 1975 traverses the time between events. Emphasising the link, Te Whenua explains that this Taonga is the very one that Whina Cooper took with her. History is repeating itself and symbolically the people from 1975 are depicted walking alongside those on the 2004 Hikoi.

The framing of the Hikoi as a continuation of historical acts of resistance motivates a discussion of the proposed foreshore and seabed legislation as yet another confiscation of 'things Maori'. Against the backdrop of historical grievances the documentary sets up an exploration of Crown and Maori rela-

198 PACIFIC JOURNALISM REVIEW 11 (2) 2005 
tionships from a Maori perspective. As Simon Dallow's voiceover states, 'Although attention has been drawn to the foreshore and seabed in recent times, debate regarding the ownership of our coastline has a very long history'. Maori claims to the foreshore and seabed date back to $1860 \mathrm{~s}$ and $70 \mathrm{~s}$. An example of an early objection to Crown confiscation is subsequently introduced through a graphic insert depicting an historical parchment: The 1869 petition of Tanameha Te Moananui. Simon Dallow then provides further historical background regarding early Crown efforts to confiscate the foreshore and seabed:

In 1868 due to gold-mining in the region, the government made moves to put areas of Thames foreshore into Crown domain. Local Iwi wrote many letters of protest including the petition of Tanameha Te Moananui, from all of Ngatimaru, Ngatitamatera, and Ngati Whanaunga Pukerahui 5th August 1869.

The camera introduces John McEnteer who states that for his Iwi, 'our sentiments are the same today as those of the earlier petition. Nothing much has changed'. Illustrating this point, Simon Dallow's voiceover states 'The Iwi in Huarache won a test case in 1870 when the Native Land Court guaranteed limited titles to areas of their foreshore and seabed'. John is depicted in his office reading 'The Hauraki Tribal Lands' document and maps of land titles in Thames. He states:

The government did not like this at all and so tried to buy out titles (44 titles covering nearly 1000 acres between Thames and Tararu), all foreshore. Also in 1870, there was a proclamation issued under the Native Land Act that stated the government would take away jurisdiction of the Native Land Court's ability to be able to consider any cases relating to foreshore and seabed, which is basically the same approach being used today in the Marlborough case. To my mind I just see history repeating itself.

These sequences serve to correct historical omissions in public discourse regarding the contemporary foreshore and seabed controversy. The emphasis on historical cases illustrates how documentaries can be used to enrich public deliberation and contextualise current tensions in race relations. The documentary contextualises this protest in order to enhance public understanding 
of why Maori have reacted as they have. The use of historical footage positions the documentary as part of a legacy of responses to colonisation, rather than an isolated disruptive act. Highlighting historical catalysts for today's Hikoi adds credibility to and warrants this protest action.

\section{Reframing relationships between stakeholders to legitimate Maori grievances}

The usual framing of political activism relies on experts to identify and give meaning to the core issues that are then exemplified by those affected (Couldry \& Curran, 2002; Hodgetts et al., 2004). Coverage of protests and industrial disputes typically moves from the tranquil offices of the powerful elites to hectic picket lines (Glasgow Media Group, 1980). In the case of the Hikoi documentary testimony from experts is primarily used to support the views of people 'outside' on the front lines of the protest. It is the protesters who identify the core issues to be deliberated upon in legal and political circles. The focus on the experiences of protesters is used to establish the implications for 'real people' of ongoing tensions between Maori and the Crown. The linking of this protest action to wider political processes situates the Hikoi as a legitimate act of opposition to ongoing oppression. Difference in the status of Maori in this documentary is also reflected in the spaces and roles Maori occupy. Maori voices are not only presented on the street as protesters. Maori voices are also presented in institutional settings as legal experts. In the remainder of this section we will focus on the portrayal of the expert and institutional levels of Maori resistance and advocacy. In the following section we will focus on the reframing of protestors as active citizens seeking to be heard from the street and through the media at a national level.

The use of expert inserts is revealing in terms of the portrayal of tensions between Maori and the Crown. There were seven expert insert sequences which outline the legislation, history of foreshore and seabed grievances, the Marlborough Sounds case, ownership, customary rights, the role of the Waitangi Tribunal, and due process. Testimony in the inserts was weighted in favour of a Maori perspective through the rhetorical positioning of sources. For instance, the first insert provides an outline of the proposed legislation. The insert begins with Moana Jackson [Maori lawyer] who proposes that the proposed legislation is unfair and unjust. He notes that it simply confiscates things which the Treaty of Waitangi, common law, and the Human Rights Act recognise as belonging to Maori. Jackson's testimony is then juxtaposed with testimony from Dr. Michael Cullen [deputy PM] who refutes Jackson's claims 200 PACIFIC JOURNALISM REVIEW 11 (2) 2005 
by stating that the proposed legislation actually serves as a protection of Maori customary rights by recognising ancestral connection and reaffirming Crown ownership so as to protect wider public rights and access. Testimony from Ms Annette Sykes [Maori lawyer] is then presented as a response to Cullen. Sykes states that this legislation is unjust, is out of step with international law, and is simply a 'racially motivated' policy that subordinates the interests of Maori and elevates those of Pakeha. The sequence of these inserts is important because Cullen's comments are 'sandwiched' between two Maori legal experts. The rhetorical promotion of a Maori perspective is reflected in how Moana Jackson's view is given the primacy position and Sykes' testimony, which dismisses Cullen's stance, is given the recency position in the exchange. Further, reflecting the promotion of a Maori perspective and the creative use of editing techniques by Maori producers, the framing of this particular exchange contrasts with the general pattern identified by Barclay and Lui (2003) who found that media coverage of Maori issues shared the reverse pattern by matching Maori commentators with Pakeha commentators.

Such inserts also promote the idea that Maori have done their research, have a deep knowledge of the historical facts, and are aware of their legal rights. In particular, the 'Marlborough Sounds Case' insert is used to reinforce the proposition that the Crown has a history of denying Maori rights to appease uninformed Pakeha interests. The audience is introduced to a Pakeha lawyer, Grant Powell. Powell represents eight Iwi from the Marlborough Sounds, who in 1997 lodged a case with the Maori Land Court to assert their customary rights to the foreshore and seabed. After years of legal battles with the Crown, the claim reached the Court of Appeal and a decision was reached in June 2003. The decision of the Court of Appeal did not say that Maori owned the foreshore. It said that the Maori Land Court had the jurisdiction to determine whether or not the foreshore and seabed of the Marlborough Sounds was Maori Customary Land. The foreshore and seabed legislation is presented as a subsequent attempt to change the rules of engagement by removing this legal right. What becomes clear at this point of the documentary is the positioning of the proposed legislation as a document that has been drafted on behalf of Pakeha to deny Maori rights. To highlight the racially motivated nature of the legislation Cullen is depicted asserting that the legislation has been formulated 'in the interest of the public'. And that Maori ownership '...would not be accepted by the great majority of New Zealanders'. This 
statement is woven into the documentary exposition as being socially divisive because it asserts that Maori are separate from the public and centralises Pakeha interests as distinct from Maori interests. Cullen attempts to justify the legislation as preventing racial conflict and in response Moana Jackson asserts that the proposed legislation simply reflects how:

If a government has a choice between pacifying the majority will when that will is based on misinformation, and being just then it has two obligations - to correct that misinformation, which it has failed to do, and to act justly. If a Government fails to act justly, then it has no right to govern.

Through the construction of these exchanges and their location in the narrative after the presentation of historical evidence pointing to the ongoing nature of Maori claims to governance over the foreshore and seabed, the documentary highlights that this is not a 'new' claim to 'private ownership'. Maori never relinquished guardianship of the foreshore and seabed.

Briefly, the combination of commentary from Moana Jackson, Cullen, Annette Sykes and Grant Powell is revealing. For example, Powell's status as Pakeha serves to introduce a notion of impartiality where even a Pakeha lawyer is convinced of the legitimacy of Maori claims. Because the other two lawyers are Maori the documentary is able to also maintain a level of reasoned empathy that invokes the consequences of government legislation for Maori participating in the Hikoi. This functions to link both levels of protest action into a united effort at obtaining social justice. Subsequently, testimony from Moana Jackson is used to reinforce the suggestion that the Crown is being unreasonable and overly dismissive of Maori rights. Moana adds that at the very least the Crown should conduct longer conversations with Maori and actually consider Maori concerns. This reasonable request is denied by Cullen who, despite being aware of the historical evidence presented to viewers, again emphasises 'the public interest' over 'Maori interests'. Jackson is the last expert to speak, so the audience is left with his comment in mind. He proposes that 'the greatest tragedy of all is that this could have all been avoided. Now a legacy is left for the grandchildren where they will have to revisit it and they will have to resolve it, when it could have been resolved now. If politicians think this will go away, they are mistaken'. Such framing of the relationship between Maori and the Crown promotes a sense of history of 
ongoing abuses of the relationship and confiscations.

\section{Challenging symbolic power through an emphasis on education}

Media power is challenged when marginalised groups are able to frame issues they face and speak for themselves more or less on their own terms (Couldry \& Curran, 2002). An effective strategy for enhancing the potential of such challenges is to show dimensions of an issue that are usually omitted. This documentary differs from standard coverage of Maori grievances because it focuses on the historical rational for and unifying aspects of such protests. Maori involved in the Hikoi are also presented as being informed, organised and reasonable people. Such framing supports the legitimacy of Maori grievances and the need for public education, debate and redress. To this end the documentary appeals to the educative and nonviolent nature of the Hikoi and protesters' status as reasonable and informed citizens exercising their democratic rights.

The importance of education as a basis for this challenge to symbolic power is evident at three interwoven levels. First, expert inserts are used to provide contextual evidence to inform audience interpretations of the Hikoi. Second, Hikoi participants are depicted taking part in educational workshops where speakers from various Iwi provide information on the proposed legislation and its implications. Third, the need for balance in coverage of Maori protests is evident in sequences highlighting how media reports on events such as these are often framed to promote negative interpretations of protesters as aggressive and threatening. All three levels are overtly evident in the portrayal of the Hikoi crossing the Auckland Harbour Bridge and the subsequent convergence on Parliament.

The bridge sequence begins with the Hikoi arriving at Hato Petera College the night before the harbour crossing. Te Whenua's voiceover accompanies the passing of the Taonga from the young man who has carried it from Cape Reinga to a local man who will carry it over the bridge. The camera then cuts between a series of shots emphasising unity where people are depicted speaking to the group while Hikoi participants prepare banners for the morning's march over the Harbour Bridge. Te Whenua states, 'Educating ourselves about the foreshore and seabed legislation was an important part of our Hikoi. And time was allocated each day for different speakers'. This statement reflects the promotion of an image of protestors as informed citizens. 
Part of the speech of a young woman with a facial moko is depicted to support the unitary nature of this protest action, which follows in the footsteps of previous generations. 'We are all descended from Rangatira and we are following in their footsteps. They have never stopped fighting for us from the beginning to protect what is ours. Our Taonga and our future'. At this point an historical insert was used to introduce the historical objections for Hauraki and the need for public understanding.

The camera cuts to the Harbour Bridge as the protestors assemble and then cross the bridge. A series of shots depict the marshals for the Hikoi working with journalists to ensure more balance in coverage and to prevent images that perpetuate negative stereotypes associated with Maori protest action. One particular sequence presents journalists filming from in front of the Hikoi as the protesters approach. Standing in front of the Hikoi, Harawira addresses the journalists:

You'll get plenty of time for your shots, but then I'm going to be asking you to move back. And when I do ask I expect all you cameramen to move your colleagues back, ok. Don't put it on us so that we're looking like tough guys when in fact you guys aren't playing by the game.

Evident in this sequence is the need for Maori to manage such media events that attract attention and have the potential to be framed as adversarial acts. Media management techniques are used to promote a more balanced representation. Protest organisers are depicted continuing this marshaling work by guiding camera crews back. A voiceover from Tere then provides a verbal link to a sequence where she is watching the footage of the bridge crossing. She comments that the protest '...looks like a party hey. You know, no hassles, no problems. I haven't seen any police. Everyone is in a good mood'. This passage is significant in the context of the tradition of such protests as disruptive and aggressive events requiring police intervention. It is important to note that in order to challenge such media stereotypes the makers of the documentary do not have to comment on them directly. The documentary makers simply assert that what they are seeing is different and in doing so, can justify an alternative representation and interpretation of Maori protest action.

We have traced this bridge crossing scene from education sessions, the use of historical inserts, the crossing of the harbour bridge, and an editing 
sequence in order to highlight how Maori are actually challenging the adversarial tendency of mainstream media to represent Maori news events as bad news (Rankin \& McCreanor, 2004; Walker, 2002). Today's marchers have learnt valuable lessons from past media coverage of Maori protest actions. They are now consciously managing the media to promote more balanced portrayals of Maori protesters. This challenge to conventional representations is continued throughout the documentary and is overtly evident in the closing sequences in Wellington, where the two young women reflect on the events depicted. For instance, accompanying shots of the crowd making the final walk to Parliament are voiceovers from Tere and Te Whenua. Tere begins 'Nobody can agree how many marched that day. What was clear was their unity'. Then Te Whenua continues 'every person that was there represented another who couldn't make it'. Accompanying this statement was an image of a protester carrying the photograph, and therefore the spirit of, Whina Cooper. Tere continues, 'For many of them it was the first time they'd ever done anything like this. This wasn't a bunch of haters and wreckers, but a tidal wave of proud people'. Te Whenua continues, 'And I think everyone came with the understanding that even if we couldn't stop the legislation our objections would go down in history'. These sequences are revealing in terms of emphasising alternative and positive representations of Maori protest, community unity and the need to participate in democratic processes and create an historical record of Maori objections to the new legislation. Such statements as 'we are not wreckers' reflect the rejection of existing media framing of Maori activists as 'radicals and disrupters'. These commentaries highlight that protesters are not simply a radical minority of Maori, but have the support of the wider community who could not make the event.

\section{Conclusion}

Media coverage of race relations continues to provide a collective space within which the public can commune and construct a sense of similarity and difference (Stuart, 2003; Hippocrates, 1998). Coverage provides a site for the revision of shared myths central to different ethnic groups' understandings of each other (Peitikaninen, 2003). There are signs that the terms of reference for such deliberations may be expanding to include Maori perspectives. The advent of Maori television, renewed Maori media production, and attempts to produce more balanced portrayals of protests within mainstream coverage attests to a broadening of dialogue between Maori and Pakeha (Fox, 1990; 
Stuart, 2003; Walkers 1990). Documentaries such as Hikoi exemplify efforts to foster mutual respect and positive intergroup relations that are essential if Maori and Pakeha are to live together and to negotiate a healthy society. This documentary exemplifies the application of the civic journalism goal of including and legitimising minority perspectives in public deliberations regarding issues of social concern so as to extend public awareness (Wallack et al., 1999). This documentary attempts to legitimise increased Maori participation in the public sphere by promoting more positive self-representations that position Maori as reasoned citizens seeking equitable solutions to problems caused by colonisation, rather than as ill-informed and antagonistic radicals (cf., Curnow, Hopa \& McRae, 2002; Lambeth, Meyer \& Thorson, 1998). Long-term such documentaries can contribute to the repositioning of Maori concerns as part of 'our' collective concerns, rather than as 'their' concerns. However, such changes cannot be substantiated via the sort of media analysis presented in this article. Future research will need to include analyses of actual viewer responses.

The analysis presented in this article contributes to a growing body of literature on the role of media in either empowering or subjugating indigenous peoples (Adebanwi, 2004; Hodgetts, Masters \& Robertson, 2004). In exploring how media coverage preserves social structures that are harmful to people such work often focuses on abuses of symbolic power and criticises discriminatory representations. We have focused on this documentary as a positive intervention by Maori journalists that challenges traditional representations of Maori protests. The two young civic journalists who produced this documentary did not just work with the community to ensure indigenous voices enter public deliberations (cf., Hippocrates, 1998). They worked as members of the community who successfully merged their roles as citizen/ protesters and journalists to frame the foreshore and seabed issue from the perspective of Maori citizens, rather than the Government (Lambeth, Meyer \& Thorson, 1998; Wallack et al., 1999). Such interventions need to be considered as efforts at conscientisation, which story grievances differently and foster public understanding and support for communally focused action (Rankine \& McCreanor, 2004; Walker, 2002). As civic journalists and social scientists engaged in community research and activism we can facilitate such processes through research-based engagements with media organisations regarding the positive and negative social impacts of different representational practices surrounding Maori communities and concerns.

206 PACIFIC JOURNALISM REVIEW 11 (2) 2005 


\section{Notes}

${ }^{1}$ It is necessary to acknowledge that not all media reports present adversarial perspectives on indigenous grievances and protests. However, previous research has documented the overwhelming tendency to portray such events in a negative light.

${ }^{2}$ Acknowledging debate around civic and public journalism is beyond the scope of this article. Further information on this approach, including a practice charter can be gained from www.pjnet.org/ and an extensive bibilography from www.poynter.org/ content/content_view.asp?id=1223.

\section{References}

Abrash, B., \& Whiteman, D. (1999). The uprising of '34: Filmmaking as community engagement. Wide Angle, 21, 87-99.

Adebanwi, W. (2004). The press and the politics of marginal voices: Narratives of the experiences of the Ongoni of Nigeria. Media, Culture \& Society, 26, 763-783.

Barclay, K., \& Liu, J. (2003). Who gets voice? (Re)presentation of bicultural relations in New Zealand print media. New Zealand Journal of Psychology, 32, 3-12.

Couldry, N., \& Curran, J. (Eds.) (2002). Contesting media power: Alternative media in a networked world. Oxford: Rowman \& Littlefield.

Curnow, J., Hopa, N., \& McRae, J. (2002). Rere tu, taku manu! Discovering history, language and politics in the Maori-language newspapers. Auckland: Auckland University Press.

Fox, D. (1990). Te Karere: The struggle for Maori news. In P. Spoonley and W. Hirsh (Eds.). Between the lines: Racism and the New Zealand media (pp. 103-107). Auckland: Heinemann Reed.

Fox, D. (1992). The Maori perspective on the news. In M. Comrie and J. McGregor (Eds.). Whose News? (pp. 170-180). Palmerston North: Dunmore.

Gains, J., \& Renov, M. (1999). Collecting visible evidence. Minneapolis: University of Minnesota Press.

Glasgow Media Group (1980). Bad news. London: Routledge.

Hall, S. (1997). The work of representation. In S. Hall (Ed.). Representation: Cultural representations and signifying practices (pp. 13-75). London: Open University.

Hippocrates, C. (1998). Public Journalism: Will it work in Australia? Communication Research Unit Annual Conference. Old Parliament House, Canberra, 24-25 September.

Hodgetts, D., Masters, B., and Robertson, N. (2004). Media coverage of 'decades of disparity' in ethnic mortality trends in Aotearoa. Journal of Community and Applied Social Psychology, 14, 1-18.

Lambeth, E., Meyer, P., and Thorson, E. (Eds.) (1998). Assessing public journalism. Columbia: University of Missouri.

Maihi, R. (2003). The foreshore and seabed: Maori customary rights and some legal issues. Wellington: New Zealand Parliamentary Library. 
Peitikaninen, S. (2003). Indigenous identity in print: Representations of the Sami in news discourse. Discourse \& Society, 14, 581-609.

Rankin, J., \& McCreanor, T. (2004). Colonial coverage: Media reporting of a bicultural health research partnership. Journalism, 5, 5-29.

Spoonley, P., \& Hirsh, W. (Ed.) (1990). Between the lines: Racism and the New Zealand media. Auckland: Heinemann Reed.

Stuart, I. (2003). The construction of a national Maori identity by Maori media. Pacific Journalism Review, 9, 45-58.

Walker, R. (1990). The role of the press in defining Pakeha Perceptions of the Maori. In P. Spoonley and W. Hirsh (Eds.). Between the lines: Racism and the New Zealand media (pp. 37-46). Auckland: Heinemann Reed.

Walker, R. (2002). Maori news is bad news. In M. Comrie and J. McGregor (Eds.), What News? (pp. 215-232). Palmerston North: Dunmore Press.

Wallack, L., Woodruff, K., Dorfman, L., and Daiz, I. (1999). News for a change: An advocate's guide to working with the media. London: Sage.

Whaanga, P. (1990). Radio: Capable of carrying a bicultural message? In P. Spoonley and W. Hirsh (Eds.). Between the lines: Racism and the New Zealand media (pp. 59-68). Auckland: Heinemann Reed.

Dr Darrin Hodgetts is an academic staff member in the University of Waikato's Department of Psychology. Alison Barnett, Andrew Duirs, Jolene Henry and Anni Schwanen are graduate students in the department. This article was written as part of a graduate community psychology research practicum class. dhdgetts@waikato.ac.nz 
Copyright of Pacific Journalism Review is the property of Auckland University of Technology and its content may not be copied or emailed to multiple sites or posted to a listserv without the copyright holder's express written permission. However, users may print, download, or email articles for individual use.

http://Mww.aut.ac.nz/depts/commstud/journ/pjrsubs.shtml 